\title{
Effect of Lime and Farmyard Manure on the Concentration of Cadmium in Water Spinach (Ipomoea aquatica)
}

\author{
Subash Chandra Shaha, Md. Abul Kashem, and Khan Towhid Osman \\ Department of Soil Science, University of Chittagong, Chittagong 4331, Bangladesh \\ Correspondence should be addressed to Md. Abul Kashem, kashem00@yahoo.com
}

Received 3 April 2012; Accepted 10 May 2012

Academic Editors: M. Arias-Estévez, N. Bellaloui, R. Burt, R. Islam, and Y. Ito

Copyright ( $) 2012$ Subash Chandra Shaha et al. This is an open access article distributed under the Creative Commons Attribution License, which permits unrestricted use, distribution, and reproduction in any medium, provided the original work is properly cited.

\begin{abstract}
An experiment was conducted to investigate the effect of lime and farmyard manure on the concentration of cadmium in water spinach. Water spinach (Ipomoea aquatica cv. Kankon) was grown in sandy loam soil spiked with $5 \mathrm{mg} \mathrm{Cd} \mathrm{Kg}^{-1}$ with lime (L) and farmyard manure (M) amendments. The treatments consisted of control, four levels of $\mathrm{L}\left(5,10,15\right.$, and $\left.20 \mathrm{tha}^{-1}\right), \mathrm{M}(5,10,15$, and $\left.20 \mathrm{tha}^{-1}\right)$, and their combinations $\left(5+5,10+10,15+15\right.$, and $\left.20+20 \mathrm{tha}^{-1}\right)$. Growth parameters of water spinach increased significantly with the addition of lime and farmyard manure in the soil. Lime addition to soil decreased Cd concentration in both shoot and root of water spinach. In control $(0+0)$, Cd concentration was $62.67 \mathrm{mg} \mathrm{kg}^{-1}$ in shoot, and $135.5 \mathrm{mg} \mathrm{kg}$ in root. Cadmium concentration decreased by 72,15 , and $66 \%$ over the control in shoot and 82,28 , and $76 \%$ in the roots correspondingly with the highest rate of lime $\left(20 \mathrm{tha}^{-1}\right)$, manure $\left(20 \mathrm{tha}^{-1}\right)$, and lime plus manure combinations $\left(20 \mathrm{tha}^{-1}+20 \mathrm{tha}^{-1}\right)$. The results imply that 5 to $10 \mathrm{tha}^{-1}$ lime could be used in Cd-contaminated soils to reduce Cd uptake by agricultural crops.
\end{abstract}

\section{Introduction}

Intensive industrial activities and agricultural development can usually cause environmental problems due to heavy metal contamination. Under natural conditions, concentration of heavy metals, especially cadmium $(\mathrm{Cd})$ is low in soils, except in those derived from shales [1]. Considerable amount of Cd can be introduced into soils via anthropogenic pathways such as dumping industrial effluents, agricultural application of sewage sludge [2], and the addition of commercial fertilizers [3]. Cadmium is not essential to biota and it is toxic to human at lower concentrations than those toxic to plants. Its effect on humans is cumulative. Crops grown on $\mathrm{Cd}$-contaminated soils are one of the sources of Cd transport to humans [4]. The limit of cadmium concentration in soil associated to biomass reduction for the majority of agricultural plants is reported to be between 5 and $15 \mathrm{mg} \mathrm{Cd} \mathrm{kg}^{-1}$ of soil [5]. Growth reduction of lettuce by $23 \%$ by the addition of $4 \mathrm{mg} \mathrm{Cd} \mathrm{kg}^{-1}$ was found in a loamy sand soil [6].

Therefore, it is necessary to develop techniques to treat and stabilize heavy metals in situ in an effective and cost effective manner [7]. An approach towards this is to render the metals immobilized by using different amendments. Lime, phosphates, or organic matter residues are commonly employed for metal immobilization in soils [8]. Lime is often chosen because it changes the forms of the metals rendering them less bioavailable. Liming is a well-known practice for controlling uptake of $\mathrm{Cd}$ by plants $[9,10]$. It was found that the addition of lime decreased the Cd concentration in rice by $25 \%$ [11]. In another experiment it was found that lime plus Zn fertilizer strongly reduced cadmium uptake by lettuce [12].

Some scientists found that application of commercial $\mathrm{MgO}$ into a Cd-contaminated paddy soil reduced the $\mathrm{Cd}$ uptake effectively [13]. The effect lies in the rise of soil $\mathrm{pH}$ which decreases $\mathrm{Cd}$ availability through increasing $\mathrm{Cd}$ adsorption. The rise in $\mathrm{pH}$ due to liming leads $\mathrm{Cd}^{2+}$ to form $\mathrm{Cd}(\mathrm{OH})^{+} \cdot \mathrm{Cd}(\mathrm{OH})^{+}$has a strong affinity to soil adsorption sites compared with $\mathrm{Cd}^{2+}[14,15]$. However, increasing $\mathrm{pH}$ does not always reduce plant uptake of Cd [16, 17]. Little or no effect of liming on Cd uptake by crops was reported $[18,19]$.

Organic matter in soil strongly influences the bioavailability of $\mathrm{Cd}$. Addition of farmyard manure may be 
a strategy to reduce the accumulation of $\mathrm{Cd}$ in edible crops $[20,21]$. However, Narwal and Singh [22] suggested that the efficiency of the organic material in reducing Cd uptake was generally small. On the contrary, Hanč et al. [23] found that addition of manure increased cadmium uptake by plants. Again, Li et al. [24] found that pig, dairy cow, and chicken manures contained high $\mathrm{Cd}$ due to presence of $\mathrm{Cd}$ in their feeds.

However, earlier investigations were done to study the effects of an amendment separately, and very little has so far been understood on the interaction of farmyard manure and lime on the bioavailability and uptake of Cd by plants. On this background, the present experiment was undertaken to investigate the effect of farmyard manure and lime on the growth and concentration of $\mathrm{Cd}$ in water spinach. Water spinach was chosen as the test plant because it is an important vegetable crop often found growing in contaminated soils.

\section{Materials and Methods}

A pot experiment was conducted at the crop field of the Department of Soil Science, University of Chittagong, Bangladesh using a sandy loam surface soil. Uncontaminated soil samples were collected from nearby field, air-dried, ground and passed through $4-\mathrm{mm}$ sieve for using it in the greenhouse experiment. For laboratory analysis, a subsample was air-dried and passed through a $2-\mathrm{mm}$ sieve and stored. Soil texture was determined by hydrometer method [25]. Soil pH was measured in a $1: 2.5$ soil-to-water suspension, organic carbon by Walkley and Black [26], and cation exchange capacity (CEC) by extraction with neutral $1 \mathrm{M}$ $\mathrm{NH}_{4} \mathrm{OAc}$ [27]. Total nitrogen of soil and farmyard manure was determined by micro-Kjeldahl method as described by Jackson [28]; total phosphorus, potassium, lead, zinc, iron, and manganese were measured by AAS (Varian AA-220) after digestion with aqua regia [29].

Thirty nine plastic pots of $5 \mathrm{~L}$ capacity were taken. Four-kilogram air-dry soil was placed in each pot. Thirteen treatments: one control, four levels of lime $(\mathrm{L}=5,10,15$, and $\left.20 \mathrm{tha}^{-1}\right)$, four levels of farm yard manure $(\mathrm{M}=5,10$, 15 , and $20 \mathrm{tha}^{-1} \mathrm{CaCO}_{3}$ ), and four of their combinations $(5+5,10+10,15+15$, and $20+20)$ were given to the pots. The treatments were replicated three times. The pots were arranged in a completely randomized design. In each pot soil, $\mathrm{Cd}$ as $3 \mathrm{CdSO}_{4} \cdot 8 \mathrm{H}_{2} \mathrm{O}$ in solution form was added at the rate of $5 \mathrm{mg} \mathrm{kg}^{-1}$. Cd was added once prior to the experiment. Important properties of soil and farmyard manure used are presented in Table 1. Five water spinach (Ipomoea aquatica cv. Kankon) seeds were sown to each pot. One week after emergence, 3 seedlings were retained. Plants were irrigated as and when necessary. The plants were harvested after 45 days of growth and separated into shoots and roots. The number of leaves and plant height were recorded at the harvest. Shoots and roots were washed thoroughly first with tap water to remove adhering soil particles and then with distilled water. The plant parts were dried in an oven at $65^{\circ} \mathrm{C}$ for 72 hours and dry mass was recorded. Plant
TABle 1: Properties of soil and farmyard manure.

\begin{tabular}{lcc}
\hline Properties & Soil & Farmyard manure \\
\hline Sand & $68 \%$ & - \\
Silt & $14 \%$ & - \\
Clay & $18 \%$ & - \\
$\mathrm{pH}$ & 5.3 & 6.8 \\
Organic carbon & $0.71 \%$ & $25 \%$ \\
Total N & $0.10 \%$ & $1.88 \%$ \\
CEC & $6.02 \mathrm{cmol} \mathrm{kg}^{-1}$ & - \\
Total P & $0.03 \%$ & $0.35 \%$ \\
Total K & $0.24 \%$ & $1.79 \%$ \\
Total Cd & Below the detection limit & $0.30 \mathrm{mg} \mathrm{kg}$ \\
Total $\mathrm{Pb}$ & $\left(0.03 \mathrm{mg} \mathrm{kg}^{-1}\right)$ & - \\
Total $\mathrm{Zn}$ & $7.4 \mathrm{mg} \mathrm{kg}^{-1}$ & - \\
Total $\mathrm{Mn}$ & $57 \mathrm{mg} \mathrm{kg}^{-1}$ & - \\
\hline
\end{tabular}

samples were grounded in a stainless steel grinder. Plant sample was digested with nitric-perchloric acids [30] and $\mathrm{Cd}$ concentration in the digest was measured by Atomic Absorption Spectrophotometer (Varian spectra AA-220). MINITAB program [31] was used for statistical analysis of data using General Linear Model (GLM) procedure.

\section{Results}

Plant growth parameters, cadmium concentrations in roots and in shoots of water spinach, and soil pH were affected by lime and farmyard. The interaction of lime and farmyard manure was not found significant in most cases (Table 2).

3.1. Growth of Water Spinach. Height of plants after 45 days of growth varied from $44 \mathrm{~cm}$ in control to $64 \mathrm{~cm}$ in $20 \mathrm{tha}^{-1}$ lime plus $20 \mathrm{tha}^{-1}$ farmyard manure (L20 + M20) treated pots (Table 3 ). In these Cd spiked soils, both lime and manure similarly increased the height of plants, but height increased more when lime and manure were added at the highest dose. Similar response was found in the number of leaves. The total number of leaves per plant varied from 16 in control to 24 in $20 \mathrm{tha}^{-1}$ lime plus $20 \mathrm{tha}^{-1}$ farmyard manure (L20 + M20) treated pots. All the growth parameters showed an increasing trend with the increasing doses of lime and manure. Dry weight of shoot of water spinach ranged from 0.78 g plant $^{-1}$ in control to $3.83 \mathrm{~g} \mathrm{plant}^{-1}$ in $20 \mathrm{tha}^{-1}$ lime plus $20 \mathrm{tha}^{-1}$ farmyardmanure-treated pots. Dry weight of shoot increased sharply with the increase of doses of lime, manure, and combined lime plus manure. Among amendments, L plus $\mathrm{M}$ treatments yielded higher shoot dry matter ( 1.93 to 3.83 g plant $^{-1}$ ) than only lime treatments. Dry weight of shoot was relatively higher with manure treatment $\left(2.42\right.$ to 2.90 g plant $\left.^{-1}\right)$ than with lime treatments ( 1.41 to 2.45 g plant $^{-1}$ ) when they were applied separately. Dry weight of root of water spinach also increased with an increase in rates of lime, manure, and lime plus manure treatments. Dry weight of root varied 
TABLE 2: ANOVA ( $F$ values) of experimental parameters.

\begin{tabular}{|c|c|c|c|c|c|c|c|c|c|}
\hline $\begin{array}{l}\text { Sources of } \\
\text { variation }\end{array}$ & $\begin{array}{c}\text { Plant } \\
\text { height }\end{array}$ & $\begin{array}{c}\text { Number of } \\
\text { leaves }\end{array}$ & $\begin{array}{c}\text { Fresh weight } \\
\text { of root }\end{array}$ & $\begin{array}{c}\text { Fresh weight } \\
\text { of shoot }\end{array}$ & $\begin{array}{c}\text { Dry weight of } \\
\text { root }\end{array}$ & $\begin{array}{c}\text { Dry weight of } \\
\text { shoot }\end{array}$ & $\begin{array}{l}\text { Cd conc. } \\
\text { in root }\end{array}$ & $\begin{array}{l}\text { Cd conc. } \\
\text { in shoot }\end{array}$ & Soil $\mathrm{pH}$ \\
\hline Lime & $15^{* *}$ & $16^{* *}$ & $8^{* *}$ & $5^{*}$ & $6^{*}$ & $16^{* *}$ & $98^{* *}$ & $230 * *$ & $156^{* *}$ \\
\hline FYM & $39 * *$ & $23^{* *}$ & $25^{* *}$ & $63^{* *}$ & $22^{* *}$ & $53^{* *}$ & $7^{*}$ & ns & ns \\
\hline Lime $\times$ FYM & ns & ns & ns & $8^{* *}$ & ns & $6^{*}$ & ns & ns & ns \\
\hline
\end{tabular}

*,** Significant at $P<0.05$ and $P<0.01$, respectively; ns: not significant.

TABLE 3: Growth parameters of water spinach and soil $\mathrm{pH}$ after harvest.

\begin{tabular}{|c|c|c|c|c|c|c|c|}
\hline Treatments & $\begin{array}{c}\text { Plant height } \\
(\mathrm{cm})\end{array}$ & $\begin{array}{c}\text { Number of } \\
\text { leaves }\end{array}$ & $\begin{array}{c}\text { Fresh weight of } \\
\text { shoot }(\mathrm{g})\end{array}$ & $\begin{array}{c}\text { Fresh weight of } \\
\text { root }(\mathrm{g})\end{array}$ & $\begin{array}{c}\text { Dry weight of } \\
\text { shoot }(\mathrm{g})\end{array}$ & $\begin{array}{l}\text { Dry weight of } \\
\text { root }(\mathrm{g})\end{array}$ & Soil pH \\
\hline Control & $44 \mathrm{e}$ & $16 \mathrm{e}$ & $7.40 \mathrm{f}$ & $1.42 \mathrm{f}$ & $0.78 \mathrm{i}$ & $0.73 \mathrm{~g}$ & $5.36 \mathrm{c}$ \\
\hline $\mathrm{L} 5+\mathrm{M} 0$ & $46 \mathrm{e}$ & $17 \mathrm{de}$ & 8.98 ef & $1.81 \mathrm{f}$ & $1.41 \mathrm{~h}$ & $0.95 \mathrm{fg}$ & $6.80 \mathrm{~b}$ \\
\hline $\mathrm{L} 10+\mathrm{M} 0$ & $48 \mathrm{de}$ & $17 \mathrm{de}$ & $10.53 \mathrm{de}$ & $2.02 \mathrm{f}$ & $1.93 \mathrm{~g}$ & $1.07 \mathrm{f}$ & $7.47 \mathrm{ab}$ \\
\hline $\mathrm{L} 15+\mathrm{M} 0$ & $49 \mathrm{de}$ & $18 \mathrm{~cd}$ & $11.87 \mathrm{~cd}$ & $2.41 \mathrm{e}$ & $2.24 \mathrm{fg}$ & $1.33 \mathrm{e}$ & $7.88 \mathrm{ab}$ \\
\hline $\mathrm{L} 20+\mathrm{M} 0$ & $51 \mathrm{~cd}$ & $19 c$ & $12.38 \mathrm{c}$ & $2.82 \mathrm{de}$ & $2.45 \mathrm{ef}$ & $1.57 \mathrm{de}$ & $8.18 \mathrm{a}$ \\
\hline $\mathrm{L} 0+\mathrm{M} 5$ & $47 \mathrm{de}$ & 18 cde & $13.72 \mathrm{bc}$ & $2.24 \mathrm{f}$ & $2.42 \mathrm{ef}$ & $1.13 \mathrm{ef}$ & $5.42 \mathrm{c}$ \\
\hline $\mathrm{L} 0+\mathrm{M} 10$ & $51 \mathrm{~cd}$ & $18 \mathrm{cde}$ & $14.44 \mathrm{~b}$ & $2.50 \mathrm{~d}$ & $2.49 \mathrm{def}$ & $1.39 \mathrm{de}$ & $5.86 \mathrm{bc}$ \\
\hline $\mathrm{L} 0+\mathrm{M} 15$ & $53 \mathrm{c}$ & $19 \mathrm{~cd}$ & $15.65 \mathrm{ab}$ & $3.37 \mathrm{~cd}$ & $2.76 \mathrm{cde}$ & $1.89 \mathrm{c}$ & $5.95 \mathrm{bc}$ \\
\hline $\mathrm{L} 0+\mathrm{M} 20$ & $56 \mathrm{bc}$ & $19 \mathrm{c}$ & $15.83 \mathrm{ab}$ & $3.79 \mathrm{c}$ & $2.90 \mathrm{c}$ & $1.99 \mathrm{bc}$ & $6.08 \mathrm{bc}$ \\
\hline $\mathrm{L} 5+\mathrm{M} 5$ & $52 \mathrm{~cd}$ & $18 \mathrm{~cd}$ & $10.83 \mathrm{~d}$ & $2.18 \mathrm{e}$ & $1.93 \mathrm{fg}$ & $1.06 \mathrm{ef}$ & $7.01 \mathrm{~b}$ \\
\hline $\mathrm{L} 10+\mathrm{M} 10$ & $59 \mathrm{~b}$ & $22 \mathrm{~b}$ & $13.44 \mathrm{bc}$ & $3.44 \mathrm{c}$ & $2.67 \mathrm{cde}$ & $1.78 \mathrm{~cd}$ & $7.71 \mathrm{ab}$ \\
\hline $\mathrm{L} 15+\mathrm{M} 15$ & $62 a b$ & $24 \mathrm{a}$ & $16.38 \mathrm{a}$ & $4.51 \mathrm{~b}$ & $3.41 \mathrm{~b}$ & $2.23 \mathrm{~b}$ & $8.12 \mathrm{a}$ \\
\hline $\mathrm{L} 20+\mathrm{M} 20$ & $64 \mathrm{a}$ & $24 \mathrm{a}$ & $17.25 \mathrm{a}$ & $5.20 \mathrm{a}$ & $3.83 \mathrm{a}$ & $2.66 \mathrm{a}$ & $8.3 \mathrm{a}$ \\
\hline
\end{tabular}

Means followed by the same letter(s) in a column are not significantly different at $P<0.05$.

from 0.73 g plant $^{-1}$ in control to 2.66 g plant $^{-1}$ in $20 \mathrm{tha}^{-1}$ lime plus $20 \mathrm{tha}^{-1}$ farmyard-manure-(L20 + M20) treated pots. Among amendments, lime plus manure treatments produced higher root dry matter (1.06 to 2.66 g plant $^{-1}$ ) and lime treatments (without $\mathrm{M}$ ) had lower dry matter (0.95 to 1.57 g plant $\left.^{-1}\right)$ of root. Dry weight of root (1.13 to $1.99 \mathrm{~g} \mathrm{plant}^{-1}$ ) with manure treatments (without L) was between lime plus manure and lime treatments.

3.2. Soil $p H$. Soil $\mathrm{pH}$ values recorded after harvest of water spinach in soils of the different amendments are presented in Table 3. Soil pH of the control pot (5.36) did not change much but increased considerably in lime treated soils (6.80 in $\mathrm{L} 5+\mathrm{M} 0$ to 8.18 in L20 + M0 treatments). On the other hand, manure without lime changed soil $\mathrm{pH}$ slightly (5.42 in L0 + M5 to 6.08 in L0 + M20). Combined application of lime and manure also increased $\mathrm{pH}$ to an appreciable extent (Table 3 ).

3.3. Cadmium Concentration in Water Spinach. Concentration of $\mathrm{Cd}$ in root, shoot, and total plant was the highest in the control pots. Application of lime abruptly reduced Cd concentration in shoot and root (Table 4). For example, concentration of $\mathrm{Cd}$ in shoot and root were 62.67 and $135.5 \mathrm{mg} \mathrm{kg}^{-1}$, respectively, in the control pots. Application of $5 \mathrm{tha}^{-1}$ lime without manure reduced the concentration of $\mathrm{Cd}$ in shoot to $21.17 \mathrm{mg} \mathrm{kg}^{-1}$ and in root to $89.65 \mathrm{mg} \mathrm{kg}^{-1}$.
In the $20 \mathrm{tha}^{-1}$ lime treated pots, Cd concentration in shoot was $17.58 \mathrm{mg} \mathrm{kg}^{-1}$, indicating $72 \%$ reduction of $\mathrm{Cd}$ concentration compared to control. Manure also reduced Cd concentration in shoot and root but to a comparatively smaller extent than lime. In the $5 \mathrm{tha}^{-1}$ manure amended pots, there was a Cd concentration of $54.75 \mathrm{mg} \mathrm{kg}^{-1}$ in shoot of water spinach. Lime reduced more cadmium concentration in root than shoot. Addition of $20 \mathrm{tha}^{-1}$ reduced concentration of $\mathrm{Cd}$ in shoot to $24.26 \mathrm{mg} \mathrm{kg}^{-1}$. In the case Cd concentration reduction, addition of lime was more effective than lime plus manure treatments (Table 4). Soil pH showed significant negative correlation with concentration of $\mathrm{Cd}$ both in the shoot $(r=-0.803$ and $P=0.000)$ and in the $\operatorname{root}(r=-0.805$ and $P=0.002)$.

\section{Discussion}

In this study, growth of water spinach increased several folds with the application of farmyard manure in one hand, and decreased Cd concentration in the shoots and roots of water spinach many folds with the application of lime, on the other hand. Application of farmyard manure reduced negligible amount of Cd concentration in water spinach compared with lime.

The experimental soil was strongly acidic ( $\mathrm{pH} 5.3$ ), increased soil $\mathrm{pH}$ about 2 unit by liming. The benefit of 
TABLE 4: Concentration of cadmium in water spinach in different treatments.

\begin{tabular}{|c|c|c|c|c|}
\hline Treatments & $\begin{array}{l}\text { Cadmium concentration } \\
\text { in shoot }\left(\mathrm{mg} \mathrm{kg}^{-1}\right)\end{array}$ & $\begin{array}{l}\text { Cadmium concentration } \\
\text { in shoot }(\% \text { over control })\end{array}$ & $\begin{array}{c}\text { Cadmium concentration } \\
\text { in root }\left(\mathrm{mg} \mathrm{kg}^{-1}\right)\end{array}$ & $\begin{array}{l}\text { Cadmium concentration } \\
\text { in root ( } \% \text { over control) }\end{array}$ \\
\hline Control & $62.67 \mathrm{a}$ & 0 & $135.5 \mathrm{a}$ & 0 \\
\hline $\mathrm{L} 5+\mathrm{M} 0$ & $21.17 \mathrm{~b}$ & 66 & $89.65 \mathrm{c}$ & 34 \\
\hline $\mathrm{L} 10+\mathrm{M} 0$ & $20.25 \mathrm{~b}$ & 67 & $41.23 \mathrm{~d}$ & 70 \\
\hline $\mathrm{L} 15+\mathrm{M} 0$ & $21.83 \mathrm{~b}$ & 65 & $34.93 \mathrm{~d}$ & 74 \\
\hline $\mathrm{L} 20+\mathrm{M} 0$ & $17.58 \mathrm{~b}$ & 72 & $24.26 \mathrm{~d}$ & 82 \\
\hline $\mathrm{L} 0+\mathrm{M} 5$ & $54.75 \mathrm{a}$ & 13 & $128.50 \mathrm{a}$ & 5 \\
\hline $\mathrm{L} 0+\mathrm{M} 10$ & $53.67 \mathrm{a}$ & 14 & $111.92 \mathrm{ac}$ & 17 \\
\hline $\mathrm{L} 0+\mathrm{M} 15$ & $47.08 \mathrm{a}$ & 25 & $99.83 \mathrm{bc}$ & 26 \\
\hline $\mathrm{L} 0+\mathrm{M} 20$ & $51.17 \mathrm{a}$ & 18 & $97.92 b c$ & 28 \\
\hline $\mathrm{L} 5+\mathrm{M} 5$ & $21.08 \mathrm{~b}$ & 66 & $46.07 \mathrm{~d}$ & 66 \\
\hline $\mathrm{L} 10+\mathrm{M} 10$ & $21.67 \mathrm{~b}$ & 65 & $36.56 \mathrm{~d}$ & 73 \\
\hline $\mathrm{L} 15+\mathrm{M} 15$ & $24.25 \mathrm{~b}$ & 61 & $33.02 \mathrm{~d}$ & 76 \\
\hline $\mathrm{L} 20+\mathrm{M} 20$ & $21.83 \mathrm{~b}$ & 65 & $32.86 \mathrm{~d}$ & 76 \\
\hline
\end{tabular}

Means followed by the same letter(s) in a column are not significantly different at $P<0.05$.

liming may lie in enhancing essential nutrient availability due to raising soil $\mathrm{pH}$. Farmyard manures are good source of plant nutrients and enhanced the growth of water spinach in this study. Higher reduction of $\mathrm{Cd}$ concentration in water spinach grown in lime, treated soils agreed with the findings of other investigators [9-11, 20,32-35]. Increasing the soil $\mathrm{pH}$ by liming may cause immobilization of heavy metals [20] and reduce their availability in contaminated soils [32]. An experiment was conducted to examine the effect of liming on the accumulation of sludge-borne metals in the crop plants [33]. Their results showed that liming the soils to $\mathrm{pH} 7$ prior to sowing significantly reduced metal concentrations in carrots and spinach, although the reduction appeared to be greater for $\mathrm{Cd}, \mathrm{Ni}$, and $\mathrm{Zn}$ than for $\mathrm{Cu}$ and $\mathrm{Pb}$. Among various soil parameters known to affect the availability of $\mathrm{Cd}$, soil $\mathrm{pH}$ was considered as the most important [34]. Cadmium concentration of the plant tissue generally decreased with increased soil $\mathrm{pH}$ provided that other soil properties remained unchanged. Soil $\mathrm{pH}$ also regulates Cd extractability in soils. The increase in soil $\mathrm{pH}$ increases the adsorption of $\mathrm{Cd}$ by soils and reduces its extractability [35].

In our study, the increase of soil $\mathrm{pH}$ by liming associated with the decrease of $\mathrm{Cd}$ concentration in water spinach. Less impact of farmyard manure on the reduction of $\mathrm{Cd}$ concentration in water spinach may be explained by the findings of other investigators [36-38] Kashem and singh [36] found significant positive correlation between mobile fraction of metals and organic matter. Almås et al. [39] reported that in a pig manure treated alum shale soil, ${ }^{109} \mathrm{Cd}$ and $\mathrm{Zn}^{65}$ increased significantly in mobile fractions, with a corresponding reduction in immobile fractions. Low molecular weight organic acids may inhibit the retention of metals in the solid phase and hence increase solubility. McBride [37] reported that soluble organics can increase the solubility of metal cations bound to organic molecules. In an experiment it was found that application of cow and pig manure decreased the $\mathrm{Cd}$ concentration in the exchangeable fraction of the soil [22]. The concentration of $\mathrm{Cd}$ in wheat grown in the cow manure-amended soil was lower as compared to that grown in the soil amended either with pig manure or peat soil, indicating that the source of organic matter was a determining factor for $\mathrm{Cd}$ distribution in the soil and for Cd uptake by plants. They concluded, however, that the efficiency of the organic material in reducing $\mathrm{Cd}$ uptake was generally small.

\section{Conclusion}

Growth of water spinach (Ipomoea aquatica cv. Kankon) and concentration of cadmium were influenced by lime, farmyard manure, and their combinations. It was found that lime was the most effective in reducing cadmium concentration in shoots and roots of water spinach. The underlying cause was the elevation of soil $\mathrm{pH}$. The effect of farmyard manure was negligible in reducing $\mathrm{Cd}$ concentration but it increased biomass production of water spinach over lime mainly due to nutritional effects of farmyard manure. Application of lime could be recommended to be used to reduce Cd uptake by plants grown in Cd-contaminated acidic soils.

\section{References}

[1] B. J. Alloway and A. P. Jackson, "The behaviour of heavy metals in sewage sludge-amended soils," Science of the Total Environment, vol. 100, pp. 151-176, 1991.

[2] B. Duquet and J. C. Vedy, "Study of heavy metal speciation by physical fractioning and sequential extraction in sludge composted soil system," in Proceedings of the International Conference of Heavy Metals in the Environment, vol. 2, pp. 99102, Edinburgh, Scotland, 1991.

[3] B. R. Singh, "Trace element availability to plants in agricultural soils, with special emphasis on fertilizer inputs," Environmental Reviews, vol. 2, no. 2, pp. 133-146, 1994. 
[4] B. R. Singh and M. J. Mclaughlin, Cadmium in Soils and Plants, Kluwer Academic Publishers, 1999.

[5] L. Simon, "Cadmium accumulation and distribution in sunflower plant," Journal of Plant Nutrition, vol. 21, no. 2, pp. 341-352, 1998.

[6] U. S. Sadana and B. Singh, "Yield and uptake of cadmium, lead and zinc by wheat grown in soil polluted with heavy metals," Journal of Plant Science Research, vol. 3, pp. 11-17, 1987.

[7] W. W. Wenzel, D. C. Adriano, and R. Smith, "Phytoremediation: a plant-microbe based remediation system," in Bioremediation of Contaminated Soils, Agron Monogr, D. C. Adriano, J. M. Bollag, W. T. Frankenberger Jr., and R. C. Sims, Eds., vol. 37, pp. 457-508, Madision, Wis, USA, 1999, ASACSSA-SSSA.

[8] N. S. Bolan and V. P. Duraisamy, "Role of inorganic and organic soil amendments on immobilisation and phytoavailability of heavy metals: a review involving specific case studies," Australian Journal of Soil Research, vol. 41, no. 3, pp. 533-555, 2003.

[9] G. W. Leeper, Managing the Heavy Metals on the Land, Marcel Dekker, New York, NY, USA, 1978.

[10] T. Chen, Y. Y. Wu, and Q. X. Kong, "Amelioration of Cd contaminated soils for controlling paddy rice Cd uptake in Chanshi Irrigation Area," Environmental Science, vol. 1, pp. 7 10, 1980 (Chinese).

[11] I. Cattani, M. Romani, and R. Boccelli, "Effect of cultivation practices on cadmium concentration in rice grain," Agronomy for Sustainable Development, vol. 28, no. 2, pp. 265-271, 2008.

[12] R. L. Chaney, C. E. Green, H. A. Ajwa, and R. F. Smith, "Zinc Fertilization plus liming to reduce cadmium uptake by Romaine lettuce on Cd-mineralized Lockwood soil," in The Proceedings of the International Plant Nutrition Colloquium, vol. 16, UC Davis, 2009.

[13] T. Kikuchi, M. Okazaki, S. D. Kimura et al., "Suppressive effects of magnesium oxide materials on cadmium uptake and accumulation into rice grains. II: suppression of cadmium uptake and accumulation into rice grains due to application of magnesium oxide materials," Journal of Hazardous Materials, vol. 154, no. 1-3, pp. 294-299, 2008.

[14] N. Cavallaro and M. B. McBride, "Activities of $\mathrm{Cu}^{2+}$ and $\mathrm{Cd}^{2+}$ in soil solutions as affected by $\mathrm{pH}$," Soil Science Society of America Journal, vol. 44, no. 4, pp. 729-732, 1980.

[15] H. A. Elliott, M. R. Liberati, and C. P. Huang, "Competitive adsorption of heavy metals by soils," Journal of Environmental Quality, vol. 15, no. 3, pp. 214-219, 1986.

[16] J. E. Eriksson, "The influence of $\mathrm{pH}$, soil type and time on adsorbtion and uptake by plants of Cd added to the soil," Water, Air, and Soil Pollution, vol. 48, no. 3-4, pp. 317-335, 1989.

[17] Q. B. He and B. R. Singh, "Crop uptake of cadmium from phosphorus fertilizers: II. Relationship with extractable soil cadmium," Water, Air, and Soil Pollution, vol. 74, no. 3-4, pp. 267-280, 1994.

[18] A. Jaakkola, "Effect of fertilizers, lime and cadmium added to soil on the cadmium content of spring wheat," Journal of the Scientific Agricultural Society of Finland, vol. 49, no. 5, pp. 406414, 1977.

[19] J. T. Sims and J. S. Kline, "Chemical fractionation and plant uptake of heavy metals in soils amended with co-composed sewage sludge," Journal of Environmental Quality, vol. 20, no. 2, pp. 387-395, 1991.

[20] A. P. Jackson and B. J. Alloway, "The transfer of cadmium from sewage-sludge amended soils into the edible components of food crops," Water, Air, and Soil Pollution, vol. 57-58, pp. 873$881,1991$.

[21] U. Mathew, V. K. Venugopaj, and P. Saraswathi, "Cadmium content of plants as affected by soil application of cadmium and farmyard manure," Journal of Tropical Agriculture, vol. 40, pp. 78-80, 2002.

[22] R. P. Narwal and B. R. Singh, "Effect of organic materials on partitioning, extractability and plant uptake of metals in an alum shale soil," Water, Air, and Soil Pollution, vol. 103, no. 14, pp. 405-421, 1998.

[23] A. Hanč, P. Tlustoš, J. Száková, J. Habart, and K. Gondek, "Direct and subsequent effect of compost and poultry manure on the bioavailability of cadmium and copper and their uptake by oat biomass," Plant, Soil and Environment, vol. 54, no. 7, pp. 271-278, 2008.

[24] Y. X. Li, X. Xiong, L. Chun-ye, Z. Feng-song, L. Wei, and H. Wei, "Cadmium in animal production and its potential hazard on Beijing and Fuxin farmlands," Journal of Hazardous Materials, vol. 177, no. 1-3, pp. 475-480, 2010.

[25] G. J. Bouyoucos, "Hydrometer method improved for making particle size analysis of soils," Agronomy Journal, vol. 54, pp. 464-465, 1962.

[26] A. Walkley and I. A. Black, "An examination of the Degtjareff method for determining organic carbon in soils: effect of variations in digestion conditions and of inorganic soil constituents," Soil Science, vol. 63, pp. 251-263, 1934.

[27] Soil Survey Staff, "Procedures for collecting soil samples and methods of analysis for soil survey," Soil Survey Investigation 1, UUS Government Printing Office, Washington, DC, USA, 1992.

[28] M. L. Jackson, Soil Chemical Analysis, Printice Hall, New Delhi, India, 1973.

[29] Vadlufa, "Koningswasserauszig (Vorschlagendes) agrikulture chemischen institutes des universital boon," Beurteilung der Siedlungsabfallkomposte (SAK) als Produktionsmitted der Landwirtschaft, Heft, vol. 4, p. 731, 1975.

[30] V. D. Zheljazkov and P. R. Warman, "Comparison of three digestion methods for the recovery of 17 plant essential nutrients and trace elements from six composts," Compost Science and Utilization, vol. 10, no. 3, pp. 197-203, 2002.

[31] Minitab, Minitab Handbook, State College, Pa, USA, 2nd edition, 1992.

[32] M. J. Mench, V. L. Didier, M. Loffler, A. Gomez, and P. Masson, "A mimicked in-situ remediation study of metalcontaminated soils with emphasis on cadmium and lead," Journal of Environmental Quality, vol. 23, no. 1, pp. 58-63, 1994.

[33] P. S. Hooda and B. J. Alloway, "The effect of liming on heavy metal concentrations in wheat, carrots and spinach grown on previously sludge-applied soils," Journal of Agricultural Science, vol. 127, no. 3, pp. 289-294, 1996.

[34] B. R. Singh, R. P. Narwal, A. S. Jeng, and A. Almas, "Crop uptake and extractability of cadmium in soils naturally high in metals at different $\mathrm{pH}$ levels," Communications in Soil Science and Plant Analysis, vol. 26, no. 13-14, pp. 2123-2142, 1995.

[35] L. D. King, "Retention of cadmium by several soils of the Southeastern United States," Journal of Environmental Quality, vol. 17, no. 2, pp. 246-250, 1988.

[36] A. Kashem and B. R. Singh, "Solid-phase speciation of Cd, Ni and $\mathrm{Zn}$ in contaminated and uncontaminated tropical soils," in Trace Elements in Soil: Bioavailability, Flux and Transfer, I. K. Iskandarm and M. B. Kirkham, Eds., pp. 213-227, Lewis Publishers, Boca Raton, Fla, USA, 2001. 
[37] M. B. McBride, Environmental Chemistry of Soils, Oxford University Press, New York, NY, USA, 1994.

[38] M. Zhang, A. K. Alva, Y. C. Li, and D. V. Calvert, "Chemical association of $\mathrm{Cu}, \mathrm{Zn}, \mathrm{Mn}$, and $\mathrm{Pb}$ in selected sandy citrus soils," Soil Science, vol. 162, no. 3, pp. 181-188, 1997.

[39] A. Almås, B. R. Singh, and B. Salbu, "Mobility of cadmium109 and zinc-65 in soil influenced by equilibration time, temperature, and organic matter," Journal of Environmental Quality, vol. 28, no. 6, pp. 1742-1750, 1999. 


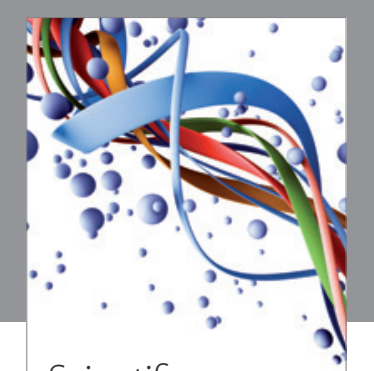

Scientifica
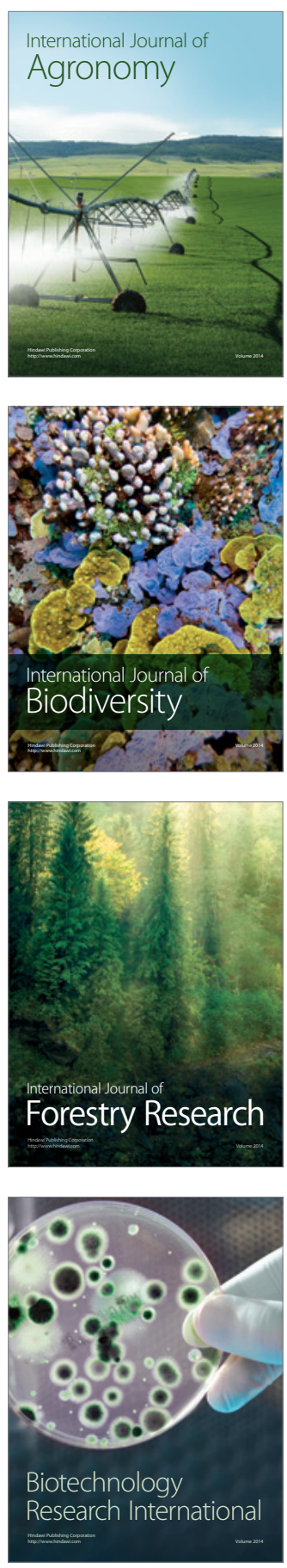
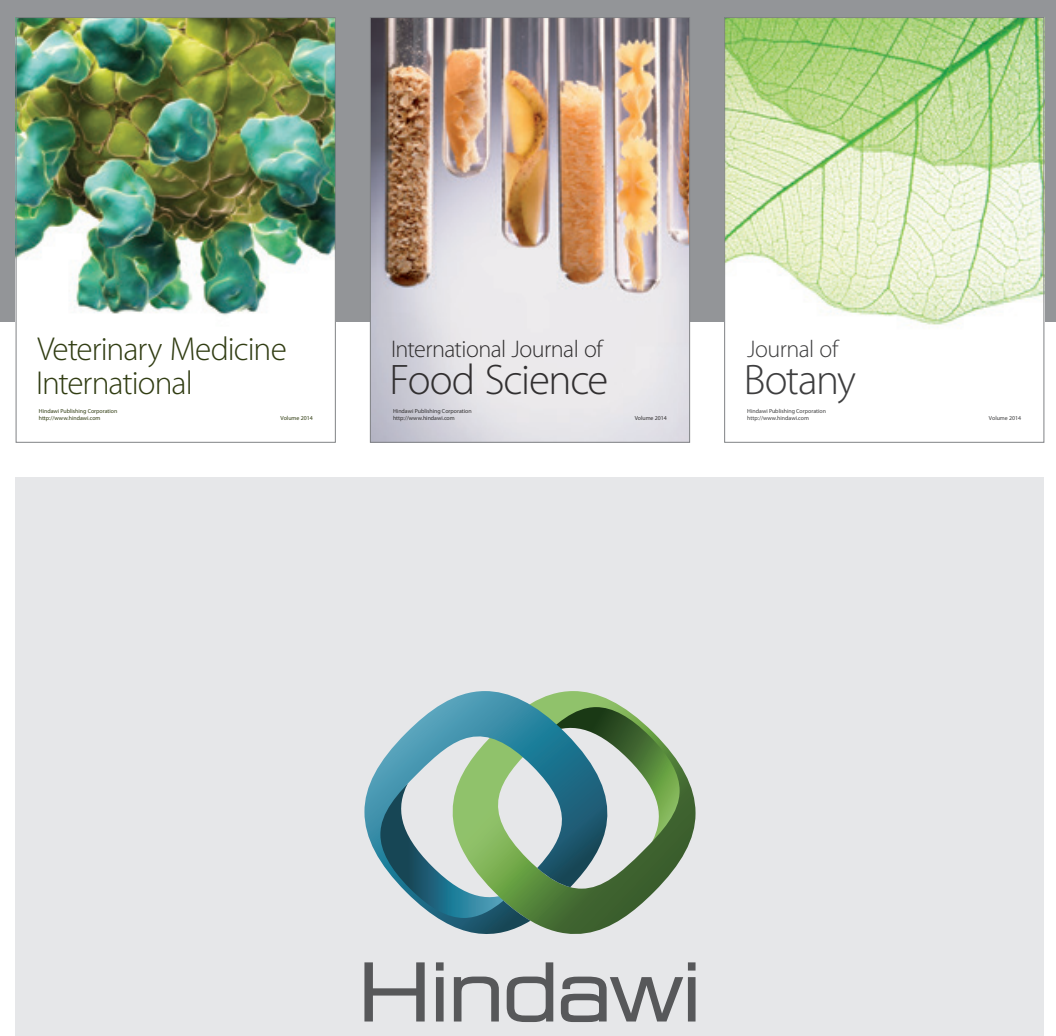

Submit your manuscripts at

http://www.hindawi.com
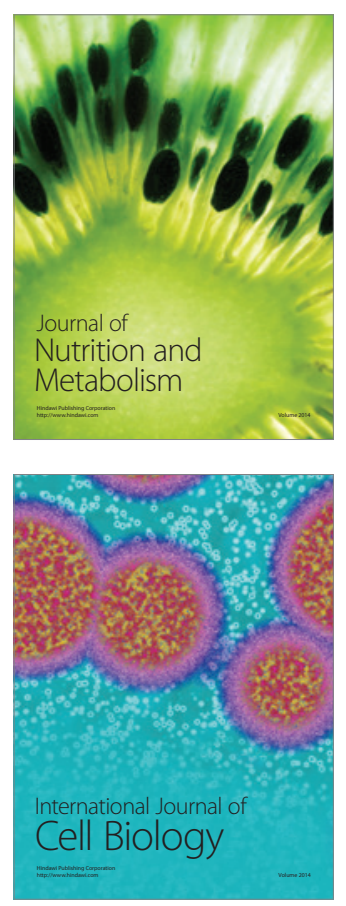
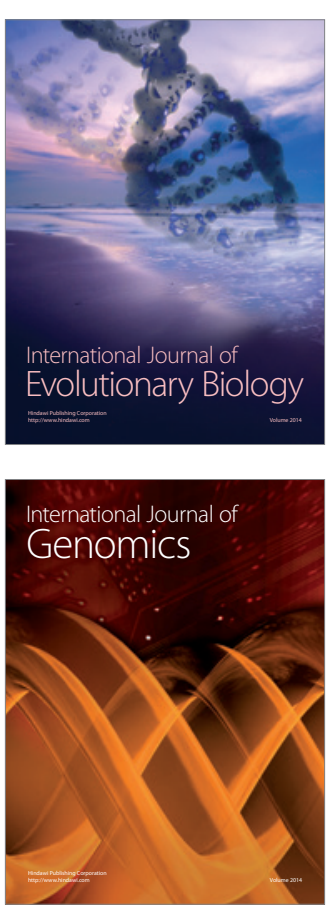
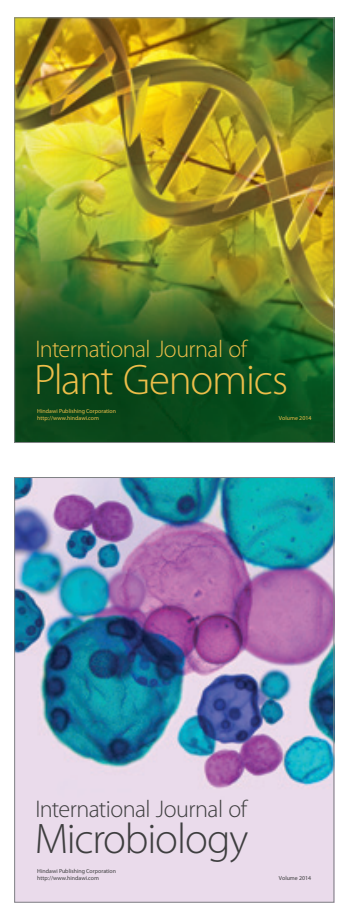

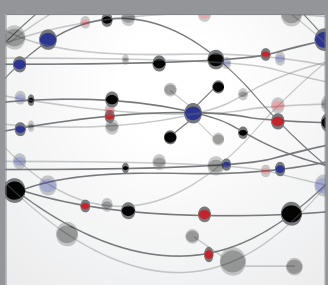

The Scientific World Journal
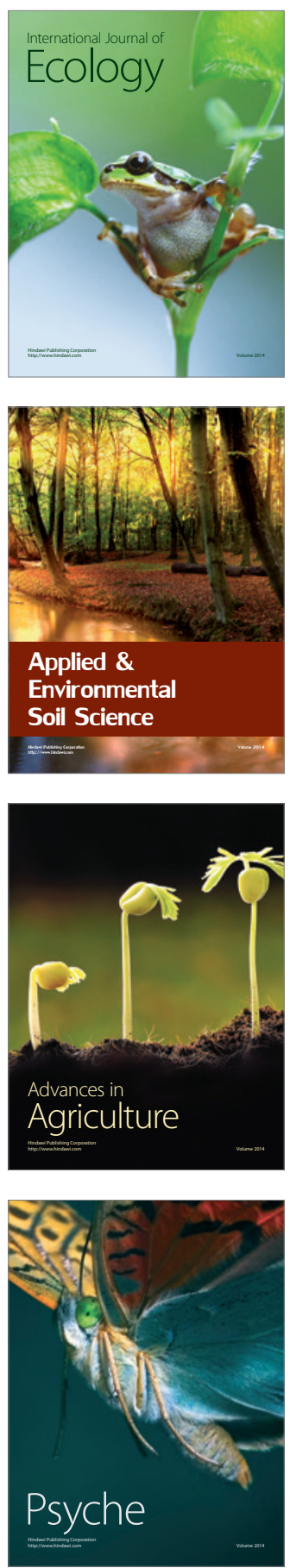